\title{
THE EVALUATION OF GEOHERITAGE FOR GEOTOURISM DEVELOPMENT: CASE STUDY ON THE POTENTIAL GEOPARK DJERDAP
}

\author{
Marija Belij ${ }^{* 1}$, Snežana Đurđić* ${ }^{*}$ Sanja Stojković* \\ * University of Belgrade - Faculty of Geography, Belgrade
}

\begin{abstract}
Geotourism is a relatively new form of tourism with considerable European and global growth potential. Interest in geotourism is developing at a very rapid rate around the world. It is of great importance to support and enhance the global movement about geotourism generally and specifically into geoparks. Geoparks are different to other forms of protected areas, such as national parks, nature reserves etc. In this paper focus of the research is on quantitative assessments of the exceptional values of geoheritage for the science, education and tourism potential use in the area of the potential Geopark Djerdap. Five selected geosites are relevant to evaluate key values for science, education, and tourism with additional consideration given to degradation risk. All the post-assessment findings aim to improve the focus on the ultimate goal of the study, i.e. to justify the synergy between the protection of natural values (geoconservation) and the corresponding activities in the process of managing the development of geotourism in the study area.
\end{abstract}

Keywords: geotourism, geoheritage, geopark, Serbia.

\section{Introduction}

Contemporary concepts of tourism development, along with the encouragement of all forms of mass tourism, intensify the creation, promotion and realization of a tourist offer directed towards specific interests of tourists. Selective forms of tourism that are realized on destinations whose basic values are insepa-

1 Corresponding author: M. Belij, University of Belgrade - Faculty of Geography, Belgrade; e-mail: marija.belij@gmail.com 
rable from preserved natural heritage are those sustainable forms of tourism activities that enable a controlled and well-balanced impact of tourism trends on the environment.

According to the previous, geotourism could be recognized as a new niche market with special interest in the geology, geomorphology, geodiversity and geography that can also provide opportunities to cultural sustainability and rural development. At present, geotourism is a new movement helping travelers to increase their knowledge about natural resources, the cultural identity of host communities, and ways of their preserving (Farsani et al., 2012). Geotourism is simply a way of combining developing concepts of tourism market segmentation (Buckley, 2003).

Table 1. Selected definitions of geotourism

\begin{tabular}{|c|c|}
\hline The definition & Reference \\
\hline $\begin{array}{l}\text { The provision of interpretive and service facilities to enable tourists to acquire knowledge } \\
\text { and understanding of the geology and geomorphology of a site (including its contribution } \\
\text { to the development of the Earth sciences) beyond the level of a mere aesthetic appreciation. }\end{array}$ & (Hose, 1995) \\
\hline $\begin{array}{l}\text { Geotourism is tourism that sustains, or even enhances, the geographical character of a } \\
\text { place, such as its culture, environment, heritage, and the well-being of its residents. }\end{array}$ & (Tourtrllot, 2000) \\
\hline $\begin{array}{l}\text { Geotourism is an emerging niche market within sustainable tourism and is centered on } \\
\text { sustaining and enhancing the geographical character of a place. }\end{array}$ & $\begin{array}{l}\text { (Stokes et al., } \\
\text { 2003) }\end{array}$ \\
\hline $\begin{array}{l}\text { Geotourism may constitute a segment of ecotourism, which is a sustainable form of } \\
\text { natural resource-based tourism that focuses primarily on experiencing and learning } \\
\text { about nature, and which is ethically managed to be low impact, non-consumptive, and } \\
\text { locally oriented (control, benefits and scale). It typically occurs in natural areas, and } \\
\text { should contribute to the conservation or preservation of such areas. }\end{array}$ & (Fennell, 2003) \\
\hline $\begin{array}{l}\text { Geotourism' will be identified as a branch of geology, important for the development of } \\
\text { the national economy. }\end{array}$ & (Hose, 2000) \\
\hline $\begin{array}{l}\text { Geotourism is multi-interest kind of tourism exploiting natural sites and landscapes } \\
\text { containing interesting Earth science features in a didactic and entertaining way. }\end{array}$ & (Pralong, 2006) \\
\hline $\begin{array}{l}\text { Geotourism is sustainable tourism with a primary focus on experiencing the Earth's } \\
\text { geological features in a way that fosters environmental and cultural understanding, } \\
\text { appreciation and conservation, and is locally beneficial. }\end{array}$ & $\begin{array}{c}\text { (Dowling \& } \\
\text { Newsome, 2006) }\end{array}$ \\
\hline $\begin{array}{l}\text { Geotourism is tourism based on an area's geological or geomorphological resources that } \\
\text { attempts to minimize the impacts of this tourism through geoconservation management. }\end{array}$ & (Gray, 2008) \\
\hline $\begin{array}{l}\text { Geotourism comprises the geological elements of form and process combined with } \\
\text { the components of tourism such as attractions, accommodation, tours, activities, } \\
\text { interpretation and planning and management. }\end{array}$ & $\begin{array}{c}\text { (James \& Hose } \\
\text { 2008) }\end{array}$ \\
\hline $\begin{array}{l}\text { Geotourism celebrates sense of place while supporting principals of conservation related } \\
\text { to a destination's natural resources, culture, heritage, and traditions. It incorporates travel } \\
\text { sectors such as lodging, shopping, entertainment, dining, and touring when they provide } \\
\text { and promote authentic experiences distinctive to the character of the locale, and do so in } \\
\text { a way that benefits the local community. }\end{array}$ & $\begin{array}{l}\text { (Miller \& } \\
\text { Washington, } \\
\text { 2009) }\end{array}$ \\
\hline $\begin{array}{l}\text { Geotourism represents a special niche in the tourist market, tourism of special interests, } \\
\text { a special form of tourism that supports and promotes objects of natural and cultural } \\
\text { heritage (which have geocomponents in its basis), educational and active content, and } \\
\text { which covers the most diverse objects of natural and cultural heritage, satisfy the cognitive } \\
\text { component, and the local community generates economic benefits. }\end{array}$ & $\begin{array}{c}\text { (Белиј, С. \& } \\
\text { Белиј, М, 2012) }\end{array}$ \\
\hline
\end{tabular}


Among numerous definitions (Table 1) it is obvious that geotourism is a form of natural area tourism that specifically focuses on geology and landscape. It promotes tourism to geosites and the conservation of geodiversity and an understanding of Earth sciences through appreciation and learning. This is achieved through independent visit to geological features, use of geo-trails and view points, guided tours, geo-activities and patronage of geosite visitor centers (Newsome and Dowling, 2010). Geotourism has strong connection with ecotourism and cultural tourism, but at the same time links with adventure tourism.

Recognizing the basic and original characteristics of geotourism, it is certain that it's inseparable connection with the protection of geological heritage, but also with a complex of other natural values. The scientific literature reveals a multitude of concepts and definitions concerning geodiversity, geological heritage, geosites, and geoconservation (Black and Gonggrijp 1990; Gray 2008, 2013; Pena dos Reis and Henriques 2009; Wimbledon 2011). Geoheritage has its intrinsic values whose sustainability is associated with adequate geoconservation, i.e. measures and management activities that can only be realized in situ.

Geotourism is adequately developed and implemented in traditional protected areas (e.g. national parks, nature reserves, etc.), but also in specialized areas such as geoparks that promote the sustainable development of tourism, the protection of geoheritage and its presentation through the education of a wide range of interest groups. The concept of geoparks defined as a geographical area where geological heritage sites are part of a holistic concept of protection, education and sustainable development should take into account the whole geographical setting of the region, and shall not solely include sites of geological significance.

Adequately to that approach and according to Carvalho and Rodrigues (2010), geotourism is not just organizing tourism in geoparks, it involves seven elements that must be always in close connection in a geopark, such as geological heritage, other heritage, tourist facilities, education, interpretation, geoconservation and local development for tourism diversification of the territory. In geoparks, tourists can see something different from other tourism activities. Nowadays geoparks are ideal destinations for tourists, since, as living outdoor museum and messengers of geotourism, they apply innovative strategies, which not only improve the local economy but also develop tourist' knowledge.

For the previously discussed reasons, the main aim of this research is to evaluate possibilities of geotourism development into case study area of potential Geopark Djerdap, Serbia, in conditions when it is necessary to preserve synergy between geodiversity, biodiversity and cultural values and heritage. Analyzing the complex relationships between the identified scientific values (SV), potential educational (PEU) and tourist activities (PTU) and associated degradation 
risk (DR) on selected representative geosites (Djerdap gorge, Boljetinska River gorge, Ploče - Mali kazan, Rajkova cave and Vratna natural bridge), quantitative assessment was carried out in order to highlight the current advantages and disadvantages for development of geotourism.

\section{Materials and methods}

The territory of potential Geopark Djerdap overlaps with the area of the largest Nation Park in Serbia, NP Djerdap. The National Park Djerdap, with an area of $638 \mathrm{~km}^{2}$ has been under legal protection since 1974. The territory of NP Djerdap is naturally predisposed by the course of the River Danube, which has dissected the Carpathian mountain system and connected the Pannonian and Pontian basins. The valley of River Danube through Djerdap gorge on the length of $100 \mathrm{~km}$ is composite, polygenetic, polyphase, and transverse, with the dominant influence of tectonics in its formation. The highest point of National Park is located on Miroč Mountain $(768 \mathrm{~m})$. On the same territory are located 14 natural reserves and 55 geoheritage sites that are under national protection status mainly as natural monuments. According to the results of research of Dragićević et al (2013), area of National Park Djerdap is affected by various natural hazards (mostly landslides and rock falls). In the same area, numerous pits and caves are found, and some might be prone to collapse due to natural factors, in particular earthquakes or anthropogenic effects. There are 11 sites that are most vulnerable to this hazard within the observed territory. This hazard should not be neglected because it threatens the speleological objects of the national park (the most significant are those located on Miroč mountain), which represent a significant part of the geological heritage of Serbia (Dragićević et al., 2013).

The potential Geopark Djerdap is nominated in 2017 on the total surface area of $1330 \mathrm{~km}^{2}$. It comprises four municipalities (Golubac, Majdanpek, Kladovo and Negotin) that belong to the administrative districts of Bor and Branicevo. It will cover complete area of the NP Djerdap, but also will include enlarged territory that has specific geoheritage sites protected by Serbian Law of Nature Protection in status of natural monuments (e.g. Rajkova cave and Vratna natural bridge). In total, it will have 63 geoheritage sites (sites of geological, geomorphological, landscapes - viewpoints, hydrological and geoarcheological importance) and Geopark Djerdap will be part of UNESCO GGN (Global Geoparks Network). 


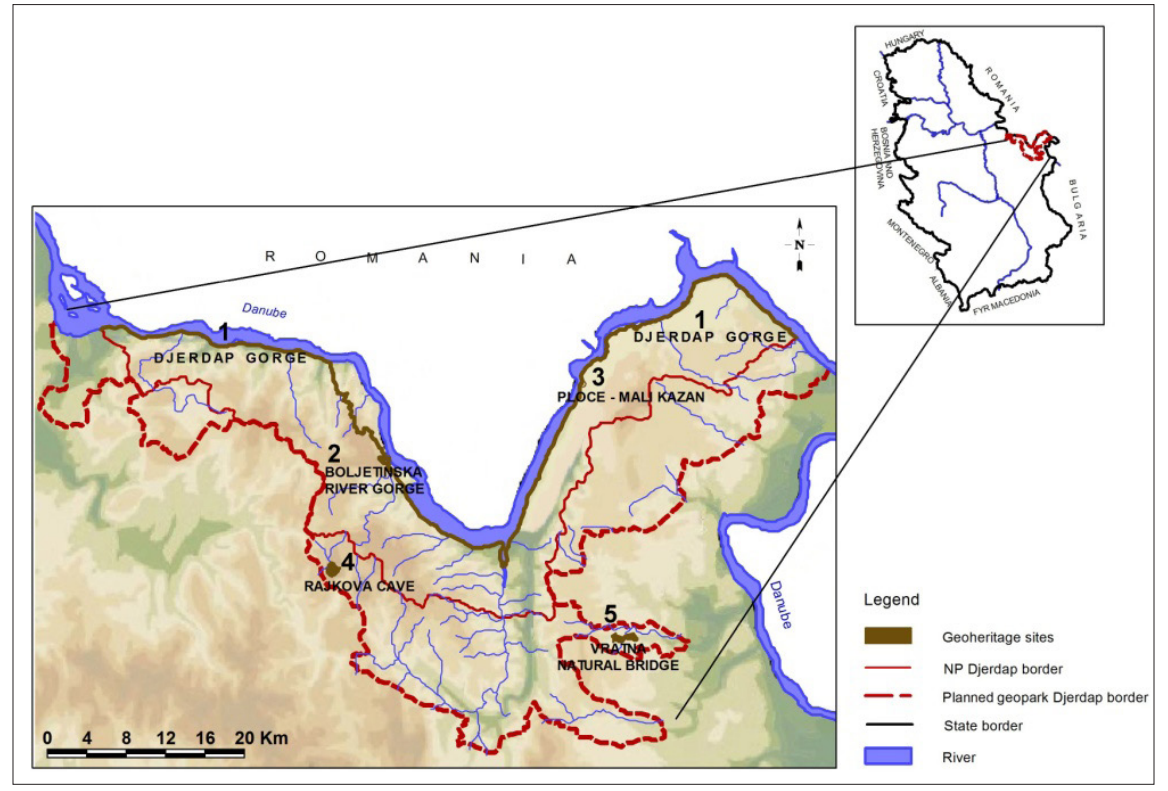

Figure 1. The geographical position of study area

For the purpose of synchronized development of tourism as well as protection of nature, it is essential that there are legal planning documents of protection and management. Of the crucial importance for study area are The Spatial plan of the area of special purpose of National Park Djerdap (Službeni glasnik RS, 43/13) and Management plan of visitors in the National Park Djerdap (Пabлobuћ et al., 2018).

The significance of the study area for the evaluation of potentials for the development of selective forms of tourism has been confirmed by numerous published research results so far. Of particular interest are the results related to the development of ecotourism (Stojković et al., 2015; Gigović et al., 2016), cultural tourism (Belij et al, 2013; Belij et al, 2014; Belij, 2017) and attitudes of local population (Brankov et al., 2015). Their importance is highlighted, because in addition to geodiversity, biodiversity, landscape scenery and both tangible and non-tangible cultural heritage are an integral part of each geopark and variety of their values can be demonstrated as tourist attractions.

The candidate area is also known, nationally and internationally, for its exceptional cultural and historical monuments dating from the Mesolithic period to modern times. The Djerdap area has the opportunity to become a unique natural laboratory - an open-air museum in which geological, ecological and civilization history of this part of Southeast Europe will be presented and interpreted to visitors in an exciting and engaging way. 
In recent years, a wide range of techniques and methods have been applied when evaluating geoheritage potentials for geotourisam development. Usually, quantitative methods are based on several criteria and respective indicators to which different scores or parameters may be assigned (Coratza and Giusti 2005; Pralong and Reynard 2005; Pereira et al. 2007; Reynard et al. 2007; Pereira and Pereira 2010; Bruschi et al. 2011; Fassoulas et al. 2012; Pereira and Pereira 2012; Bollati et al. 2013). The aim of a quantitative assessment is to decrease the subjectivity associated with any evaluation procedure. The result of this numerical assessment is a sorted list of sites, which is a powerful tool for the establishment of management priorities. Sites with higher value should be given top priority.

For the study area, a modified method of quantitative assessment of geosites of Brilha (2016) has been selected for potential touristic use (PTU), taking into account specifics of scientific value (SV), potential educational use (PEU) and degradation risk (DR) which are inseparable from the sustainable development of geotourism.

The evaluation was carried out in accordance with field research, official data from the management of NP Djerdap and on the basis of the most recent results of relevant published scientific researches.

\section{Discussion of results}

Among 63 geoheritage sites in potential Geopark Djerdap in accordance with preferences of the potential for geotourism development were selected and evaluated five geosites (Djerdap gorge, Boljetinska river gorge, Ploče - Mali kazan, Rajkova cave and Vratna natural bridge). The geoheritage sites selection were based on following attributes: phenomenon origin, most visited sites, geographical location (location only within National park/location within Geopark) and significance (scientific, educational or geotouristic). The geodiversity elements, including the high potential for certain types of use, combined with the high degradation risk, demand a higher priority in protection and management policy (Nguyen-Thuy et al., 2018).

Each quantitative assessment criterion (Table 2) is scored from a value 0 (corresponding to the lowest) to a value 4 (corresponding to the highest) and the final evaluation of the touristic value is the result of the weighted sum of the scores. Different criteria have different weights which reflect distinctions in the relative importance of those same criteria (Table 2). 
Table 2. Evaluation of potential uses for geotourism (details of scoring parameters for each criterion followed the quantitative assessment of geosites in Brilha, 2016)

\begin{tabular}{|c|c|c|c|c|c|c|c|c|c|c|c|c|c|}
\hline \multirow{3}{*}{$\begin{array}{l}\text { Criterion } \\
\text { Representativeness }\end{array}$} & \multicolumn{5}{|c|}{ Geosite } & \multirow{2}{*}{\multicolumn{4}{|c|}{ Aim of evaluation }} & \multirow{2}{*}{\multicolumn{4}{|c|}{ Weight (\%) }} \\
\hline & \multirow{2}{*}{\begin{tabular}{|c|}
$\# 1$ \\
4
\end{tabular}} & \multirow{2}{*}{$\frac{\# 2}{4}$} & \multirow{2}{*}{$\begin{array}{c}\# 3 \\
2\end{array}$} & \multirow{2}{*}{$\frac{\# 4}{4}$} & \multirow{2}{*}{$\begin{array}{c}\text { \#5 } \\
4\end{array}$} & & & & & & & & \\
\hline & & & & & & SV & & & & 30 & & & \\
\hline Key locality & 2 & 1 & 1 & 1 & 1 & SV & & & & 20 & & & \\
\hline Scientific knowledge & 4 & 4 & 2 & 4 & 4 & SV & & & & 5 & & & \\
\hline Integrity & 2 & 2 & 4 & 4 & 2 & SV & & & & 15 & & & \\
\hline Geological diversity & 4 & 1 & 1 & 2 & 2 & SV & PEU & & & 5 & 10 & & \\
\hline Rarity & 4 & 4 & 2 & 4 & 4 & SV & & & & 15 & & & \\
\hline Use limitations & 4 & 2 & 2 & 2 & 3 & SV & PEU & PTU & & 10 & 5 & 5 & \\
\hline Vulnerability & 2 & 3 & 4 & 3 & 3 & & PEU & PTU & & & 10 & 10 & \\
\hline Accessibility & 4 & 3 & 3 & 4 & 1 & & PEU & PTU & $\mathrm{DR}$ & & 10 & 10 & 15 \\
\hline Safety & 4 & 3 & 4 & 4 & 3 & & PEU & PTU & & & 10 & 10 & \\
\hline Logistics & 4 & 4 & 4 & 4 & 3 & & PEU & PTU & & & 5 & 5 & \\
\hline Density of population & 4 & 4 & 4 & 4 & 4 & & PEU & PTU & DR & & 5 & 5 & 10 \\
\hline $\begin{array}{l}\text { Assosiations with other } \\
\text { values }\end{array}$ & 4 & 4 & 3 & 2 & 2 & & PEU & PTU & & & 5 & 5 & \\
\hline Scenary & 4 & 3 & 3 & 4 & 3 & & PEU & PTU & & & 5 & 15 & \\
\hline Uniqueness & 4 & 3 & 4 & 3 & 3 & & PEU & PTU & & & 5 & 10 & \\
\hline Observations conditions & 3 & 2 & 3 & 4 & 3 & & PEU & PTU & & & 10 & 5 & \\
\hline Interpretative potential & 4 & 2 & 3 & 3 & 2 & & & PTU & & & & 10 & \\
\hline Economic level & 1 & 1 & 1 & 1 & 1 & & & PTU & & & & 5 & \\
\hline $\begin{array}{l}\text { Proximity of recreational } \\
\text { areas }\end{array}$ & 4 & 4 & 4 & 4 & 1 & & & PTU & & & & 5 & \\
\hline Didactic potential & 4 & 1 & 1 & 2 & 2 & & PEU & & & & 20 & & \\
\hline $\begin{array}{l}\text { Deterioration of } \\
\text { geological elements }\end{array}$ & 2 & 3 & 2 & 3 & 2 & & & & DR & & & & 35 \\
\hline $\begin{array}{l}\text { Proximity to areas/ } \\
\text { activities with potential } \\
\text { to cause degradation }\end{array}$ & 3 & 2 & 1 & 3 & 1 & & & & DR & & & & 20 \\
\hline Legal protection & 2 & 2 & 1 & 1 & 2 & & & & DR & & & & 20 \\
\hline Scientific value (SV) & 3,3 & 2,8 & 2,1 & 3,1 & 2,9 & & & & & & & & \\
\hline $\begin{array}{l}\text { Potential education use } \\
\text { (PEU) }\end{array}$ & 3,7 & 2,4 & 2,7 & 3,1 & 2,5 & & & & & & & & \\
\hline $\begin{array}{l}\text { Potential tourism use } \\
\text { (PTU) }\end{array}$ & 3,6 & 2,9 & 3,3 & 3,4 & 2,5 & & & & & & & & \\
\hline Degradation risk (DR) & 2,7 & 2,8 & 2 & 2,9 & 1,9 & & & & & & & & \\
\hline
\end{tabular}


Generally, characteristics of selected geosites are well-known in national and international scientific literature; they all have some of national legal protection statuses (integral parts of national park and nature reserves into national park, or natural monuments) and all geosites could be didactic objectives at different educational levels and have a potential for an attractive tourist presentation to the general public.

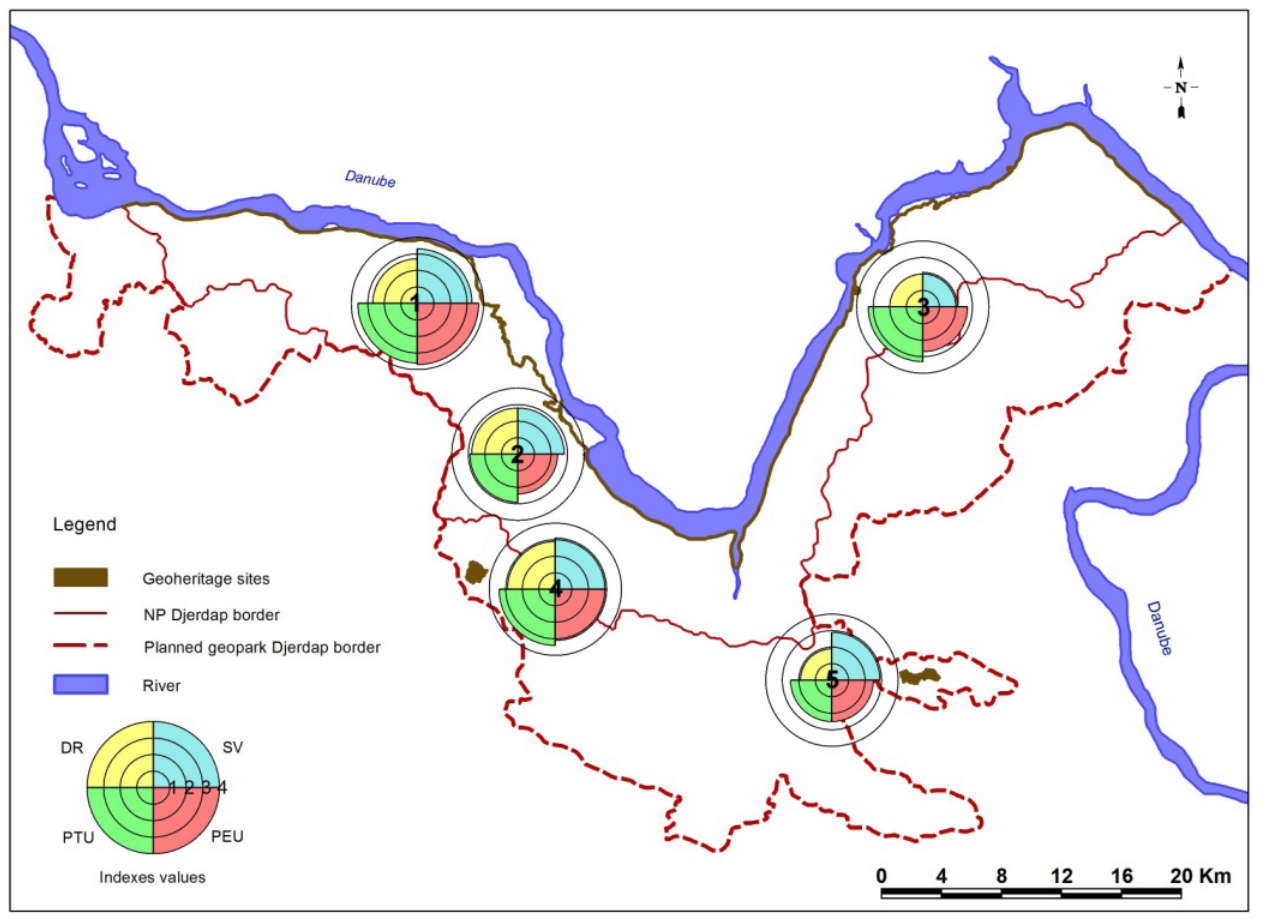

Figure 2. The quantitative assessment results of five geosites of potential Geopark Djerdap

A geosite has a high PTU when the geological and geomorphological elements have a remarkable aesthetic relevance (usually geomorphological elements are the ones with a higher potential to be aesthetically appreciated by the general public) and can be easily understood by persons with no geoscientific background, as well as being associated with a low risk of degradation by anthropogenic activity (low vulnerability). By analyzing the obtained results of a quantitative evaluation, it was found that among the selected sites with the highest potential for tourism development (PTU) was highlighted the synonym of the National park and the potential Geopark - Djerdap gorge, for tourists visits adapted Rajkova cave and viewpoint Ploče - Mali kazan, the best locality for sightseeing to the narrowest part of the Danube river gorge. Despite the 
significant scientific and educational value, the Vratna Natural Bridge geosite, by using the same methodology, is not highly valued due to the unfavorable position (traffic availability, distances from other areas of importance for recreation and tourism, poor logistical support, etc.). Similar reasons caused the relatively low assessment value of the site Boljetinska river gorge for geotourism development.

In addition to the development of tourism, in the assessment process, it is also necessary to consider the risk of degradation of basic natural values, which represent the main tourist motives and values. Namely, according to the current state, the degradation risk is the lowest at the site of the Vratna natural bridge. In all other four locations, a similar moderate degradation risk is estimated, which can be expected to increase with the intensification of the development of any form of tourism activities, not only geotourism. It is of particular importance that the managers of the potential Geopark prepare an adequate management plan for visitors, which will be based on the current state of natural values and proposed measures to overcome the potential degradation risks that can be expected with increasing anthropogenic pressure due to the development of tourism, and specifically related to the geotourism.

\section{Conclusion}

In areas with a large number of geosites, a quantitative assessment of their scientific value, potential educational use and potential tourism use, together with degradation risk, constitutes an important asset for management purposes. Using this approach, subjectivity inherent to assessment of sites is not totally eliminated but it is minimized.

According to the results in this research, it is evident that potential Geopark Djerdap obtains geosites of undeniable significance in terms of science, education, and tourism. The selected five geosites that were identified and characterized according to the global framework for geoheritage and scientific knowledge correspond to petrological formations, geomorphological landforms, and sedimentary formations. They all should be preserved for its scientific value independently of its effective immediate use (e.g. educative and touristic).

For the appropriate management process that correspond equally to the conservation and tourism use it is necessary to establish strong and efficient collaboration between local authorities and managers of protected area. Sustainability of most local geodiversity forms in the longer term is firmly in the hands of local people's interests, beliefs and desires rather than coming from an imposed expert mandate. Keeping geodiversity in the hearts and minds of the local community is greatest opportunity (and challenge) for the future management process. 
One of the elements that need to be developed is the integration of geoheritage presentation and valorization for the different purposes of geoconservation and sustainable use and results of the quantitative assessment could be helpful.

\section{References}

Belij, M., Ilincic, M., \& Belij, J. (2013). Complementarity of the "Roman Emperors Route" and the section of corridor VII passing through Serbia. International Scientific Conference Cultural Corridor Via Diagonalis - Cultural Tourism Without Boundaries 03.10.2013 - 06.10.2013. (pp. 199-209).

Белиј, С., \& Белиј, М. (2012). Геотуризам у систему одрживог туризма. У Зборник радова Проблеми и изазови савремене географске науке и наставе, (pp. 589-594). Београд: Универзитет у Београду - Географски факултет.

Белиј, С., Илинчић, М., Белиј, Ј., \& Белиј, М. (2014). Одрживо планирање и политика развоја туризма на примеру средњовековних тврђава на Дунаву. Гласник Српског географског друштва, 94(3), 69-82. doi: 98/GSGD1403069В

Belij, M. (2017). Cultural tourist motives in National parks in Serbia. Tourism in protected areas of nature in Serbia and Slovenia. University of Belgrade - Faculty of Geography, Belgrade, pp. 113-128.

Black, G.P, \& Gonggrijp, G. P. (1990). Fundamental thoughts on Earth-science conservation. Jb. Geol. B.-A. 133(4), 655-657.

Bollati, I., Smiraglia, C., \& Pelfini, M. (2013). Assessment and selection of geomorphosites and trails in the Miage Glacier Area (Western Italian Alps). Environmental Management, 51(4), 951-967.

Brankov, J., Jovičić, D., \& Milijašević, D. (2015). Sustainable tourism in National park "Đerdap", Serbia - attitudes of local population, J. Geogr. Inst. Cvijic. 65(2), 183199. doi:10.2298/IJGI1502183B

Brilha, J. (2016). Inventory and quantitative assessment of geosites and geodiversity sites: a review. Geoheritage. 8, 119-134. doi:10.1007/s12371-014-0139-3

Bruschi, V.M., Cendrero, A., \& Albertos, J.A.C. (2011). A statistical approach to the validation and optimisation of geoheritage assessment procedures. Geoheritage 3(3), 131-149.

Buckley, R. (2003). Environmental Inputs and Outputs in Ecotourism: Geotourism with a Positive Triple Bottom Line? Journal of Ecotourism, 2:1, 76-82, doi: 10.1080/14724040308668135

Carvalho, C.N., \& Rodrigues, J. (2010). Building a geopark for fostering socioeconomic development and to burst cultural pride: the Naturtejo european geopark (Portugal). In Una visión multidisciplinar del patrimonio geológico y minero. Cuadernos del Museo Geominero, ${ }^{\circ}$ 12. Instituto Geológico y Minero de España, Madrid, (pp. 467-479). 
Coratza, P., \& Giusti, C. (2005). Methodological proposal for the assessment of scientific quality of geomorphosites. II Quaternario, Italien. J Quat Sci 18(1), 307-313.

Dowling, R. \& Newsome, D. (eds) (2006). Geotourism: Sustainability, Impacts and Management. Oxford: Elsevier Butterworth-Heinemann.

Dragićević, S., Mészáros, M., Djurdjić, S., Pavić, D., Novković, I., \& Tošić, R. (2013). Vulnerability of national parks to natural hazards in the Serbian Danube region. Pol. J. Environ. Stud. 22(4), 1053-1060.

Farsani, N. T., Coelho, C., Costa, C., \& Carvalho, C. (2012). Geoparks and Geotourism: Concepts, Theories and Paradigms, In Geoparks and Geotourism: New Approaches to Sustainability for the 21st Century, Brownwalker Press Publisher, Florida, USA, (pp. 5-57).

Fassoulas, C., Mouriki, D., Dimitriou-Nikolakis, P., Iliopoulos, G. (2012). Quantitative assessment of geotopes as an effective tool for geoheritage management. Geoheritage, 4(3), 177-193.

Fennell, D. A. (2003). Ecotourism: An introduction. New York, NY: Routledge.

Gigović, Lj., Pamučar, D., Lukić, D., \& Marković, S. (2016). GIS-Fuzzy DEMATEL MCDA model for the evaluation of the sites forecotourism development: A case study of "Dunavski ključ" region, Serbia. Land Use Policy, 58, 348-365. doi: 10.1016/j.landusepol.2016.07.030

Gray, M. (2008). Geodiversity: developing the paradigm. Proceedings of the Geologists' Association, 119, pp. 287-298

Gray, JM. (2013). Geodiversity: valuing and conserving abiotic nature. John Wiley \& Sons, Chichester.

Hose, T.A. (1995). Selling the story of Britain's stone. Environmental Interpretation, 10, 2, 16-17.

Hose, T.A. (2000). European Geotourism - Geological Interpretation and Geoconservation Promotion for Tourists, In Barretino, D., Wimbledon, W.P. \& Gallego, E. (eds.) Geological Heritage: Its Conservation and Management. Madrid: Instituto Tecnologico Geominero de Espana. (pp. 127-146)

James, H.C.L. \& Hose, T.A. (2008). Are we in danger of lusing the "GEO" in Geotourism? An assessment of the geological potential of selected sites in Southern-Central Britain. In Dowling R.K. and Newsome, D. (eds.) Geotourism. Proceeding of the Inaugural Global Geotourism Conference, "Discover the Earth Beneath our Feet", Fremantle, Western Australia, (pp. 199-208).

Miller, R.K., \& Washington, K. (eds.) (2009). Geotourism,travel \& tourism market research handbook (pp. 170-172). Ireland: Key Note Publications Ltd.

Newsome D., \& Dowling R.K. (2010). Geotourism: the tourism of geology and landscape. Goodfellow Publishers, Oxford.

Nguyen-Thuy, D., Ta, P.H., Nguyen-Van, H., Dinh, H.V., Dang, B.V., Dang, N.H., Do, H.T.T., Nguyen, A.T.K., Tran, T.D., Bui, V.V., Nguyen, A.N. \& Hoang, T.T. (2018). Evaluation of Geological Heritage of Geosites for a Potential Geopark 
in Binh Thuan-Ninh Thuan Coastal Zone, Vietnam. Geoheritage. https://doi. org/10.1007/s12371-018-0324-x

Oprea-Gancevici, D., \& Cheia, G. (2012). The evaluation of the geomorphological touristic potential of mountainous areas. Case study: the Rarău Massif. Forum geografic. XI(2), 235-245. doi:10.5775/fg.2067-4635.2012.091.d

Павловић, С., Филиповић, Д., Шећеров, В., Јовичић, Д., Белиј, М., Весић, М., Тодоровић, Н. \& Протић, Б. (2018). План управљања туристима у Националном парку Бердап. Универзитет у Београду - Географски факултет.

Pereira, P., Pereira, D.I., \& Alves, M.I.C. (2007). Geomorphosite assessment in Montesinho Natural Park (Portugal). Geogr Helv., 62, 159-168.

Pereira, P., \& Pereira, D.I. (2010). Methodological guidelines for geomorphosite assessment. Géomorphologie: relief, processus, environnement, 16(2), 215-222.

Pereira, P., \& Pereira, D.I. (2012). Assessment of geosites tourism value in geoparks: the example of Arouca Geopark (Portugal). Proceedings of the 11th European Geoparks Conference, Arouca. (pp. 231-232).

Pena dos Reis, R., \& Henriques, M. H. (2009). Approaching an integrated qualification and evaluation system for geological heritage. Geoheritage, 1, 1-10.

Pralong, J.P., \& Reynard, E. (2005). A proposal for the classification of geomorphological sites depending on their tourist value. Quaternario 18(1), 315-321.

Pralong, J.P. (2006). Geotourism: A New Form of Tourism Utilising Natural Landscapes and Based on Imagination and Emotion, Tourism Review, 61(3), 20-25.

Republička agencija za prostorno planiranje (2013). Prostorni plan područja posebne namene NP Đerdap. Službeni glasnik RS, 43/13.

Reynard, E., Fontana, G., Kozlik, L., \& Scapozza, C. (2007). A method for assessing "scientific" and "additional values" of geomorphosites. Geographica Helvetica 62(3), 148-158.

Stojković, S., Đurđić, S., \& Anđelković, G. (2015). Application of multi-criteria analysis and GIS in ecotourism development (Case study: Serbian Danube region). Glasnik Srpskog geografskog društva, 95(1), 51-66. doi:10.2298/GSGD1501051S

Stokes, A., Cook, S., \& Drew, D. (2003). Geotourism: The New Trend in Travel. Travel Industry Association of America (TIA) and National Geographic Traveler, USA.

Tourtellot, J.B. (2000). Geotourism for your community, National Geographic Drafts, Washington DC, USA, p. 2.

Višnić, T., \& Began, M. (2016). Evaluation of geoheritage models - analysis and its application on the loess profiles in Vojvodina region. Forum Geographic. XV(1), 97-108. doi:10.5775/fg.2016.066.i

Wimbledon, W. A. (2011). Geosites-a mechanism for protection, integrating national and international valuation of heritage sites. Geologia dell'Ambiente, supplement, 2, 13-25. 